\title{
フェロアロイエ業の状況と進歩について（その 4）
}

田辺 伊 佐 雄*

\section{Si 系アロ 1}

\subsection{FSi (フェロシリコン) およひ MSi（メタリッ} クシリコン)

6.1.1 沿革よ規格,用途およひ性質 FSi はっっと も古くから生産されているフェロアロイの一つであり， 1808 年 Berzelius ${ }^{1}$ によってはじめて試作がなされ,1870 年には Volten 亿より 22\% FSi が製造”されている。

その後 1882 年には Hadfield 亿より FSi の製鋼へ の応用が研究されて需要が確立し, 1895 年 Chalmat ${ }^{37}$ によって電気炬による今日の製造方法が明らかにされ $50 \% \mathrm{FSi}$ が製造された。

その後 $\mathrm{Si}$ 品位は漸次高いものが製造され，現在の 75\% FSi が主として生産されるようになり, 非鉄合金, その他特殊用途に MSi の生産も行なわれて今日に到。 ている.

高炣でる 10〜20\% 品位の FSi の製造虫可能である が,さらに高品位のものの製造は困難なためもっぱら電 気炉によっている。

わが国で FSi の生産は $\mathrm{FMnH}$ と同様第一次大戦前 後にさかのぼり，鉄鋼生産にほとんど比例的に増産さ れ, 昭和 36 年度の生産は表 2 亿示す上うに FSi は $98,736 \mathrm{t}, \mathrm{MSi}$ は 7,894 $\mathrm{t}$ 亿達し，FMn につぐ生産量 をしめている。

FSi および MSi の JIS 規格は表45のようであり， FSi は 1 号から 6 号の各品種にわたっているが，そのほ とんどが 2 号品である.すなわち昭和 34〜36 年の号別

表 45 MSi および FSi の JIS 規格

\begin{tabular}{|c|c|c|c|c|c|c|c|}
\hline \multirow{2}{*}{ 種 } & \multirow{2}{*}{ 類 } & \multirow{2}{*}{ 記 昂 } & \multicolumn{2}{|c|}{ 化 } & 成 & \multicolumn{2}{|l|}{$(\%)$} \\
\hline & & & Si & C & $\mathbf{P}$ & $\mathrm{s}$ & $\mathrm{Fe}$ \\
\hline \multirow{2}{*}{ 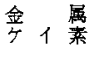 } & 1 号 & MSi 1 & 98.0 以上 & 0.10 以下 & 0.05 以下 & 0.05 以下 & 0.7 以下 \\
\hline & 2 묵 & MSi 2 & 97.0以上 & 0.10 以下 & 0.05 以下 & 0.05 以下 & $1.0 \mathrm{DF}$ \\
\hline \multirow{6}{*}{ フコニロン } & 1 号 & FSi 1 & $88 \sim 93$ & 0.2 以下 & 0.05 以下 & 0.03 以下 & \\
\hline & 2 号 & FSi 2 & $75 \sim 80$ & 0.2 以下 & 0.05以下 & 0.03 以下 & \\
\hline & 3 号 & FSi 3 & $40 \sim 45$ & 0.2 以下 & 0.05 以下 & 0.03 以下 & \\
\hline & 4 묵 & FSi 4 & $25 \sim 30$ & 0.8 D下 & 0.10 以下 & 0.10 以下 & \\
\hline & 5 号 & FSi 5 & $20 \sim 25$ & 1.0 以下 & 0.10 以下 & 0.10 以下 & \\
\hline & 6 号 & FSi 6 & $14 \sim 20$ & 1.3 以下 & 0.08 以下 & 0.06 以下 & \\
\hline 供考 & $\begin{array}{l}1 . \\
2 .\end{array}$ & 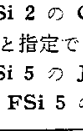 & $\neq 0$ & 見格 & 0.04 & 䉼上 & $0.03 \%$ 以 \\
\hline
\end{tabular}

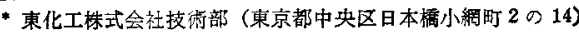

表 $46 \mathrm{FSi}$ 号別生産比率 $(\%)$

\begin{tabular}{|c|c|c|c|c|c|c|}
\hline 年次品位 & 1 & 2 & 3 & 4 & 5 & 6 \\
\hline 34 & 0 & 81.5 & 17.1 & 0.9 & 0 & 0.5 \\
\hline 35 & 0.6 & 84.7 & 13.8 & 0.2 & 0.2 & 0.5 \\
\hline 36 & 0.2 & 82.0 & 17.2 & 0.1 & 0 & 0.5 \\
\hline
\end{tabular}

生産此率 ${ }^{11)}$ 示せば表 46 のようである.

てのほか後述するように最近キユポラおよびとりべ添 加用として，FSi ブリケットおよご発熱生 FSi の生産 も行なわれている。

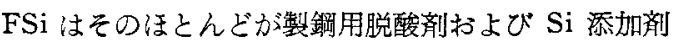
として使用されるが，てのほか2号品は Si テルミット 用還元剂押湯保温剤およびピション法における $\mathrm{Mg}$ 製鍊 時の還元凨としても使用され，6 号品は粉末として重液 選鉱用メディアム，および有機化合物還元剤としても利 用される。

MSi はシルそンなどの非鉄合金用 Si 添加刘，ならび に $\mathrm{Al}$ およびC学どの不純物がとくにきらわれるケイ素 銅用 $\mathrm{Si}$ 添加㓮およびシリコン樹脂用原料として活用さ れる．FSi 3 号はFSi 2 号とほ潘同一目的で使用され るが，後述するようにケイ素鋼用 FSi として FSi 2 号 品を脱 $\mathrm{Al}$ 処理を行なった特殊品位のものも生産のかな りの部分をしめていると考えられる。状態図れおよび含 有不純物より考慮して，FSi 2 号および 3 号の融点は $1350^{\circ} \mathrm{C}$ および $1200^{\circ} \mathrm{C}$ 近过と考光られる。

FSi は比較的ぜい性に富み，Pおよび $\mathrm{Al}$ 含有率が多

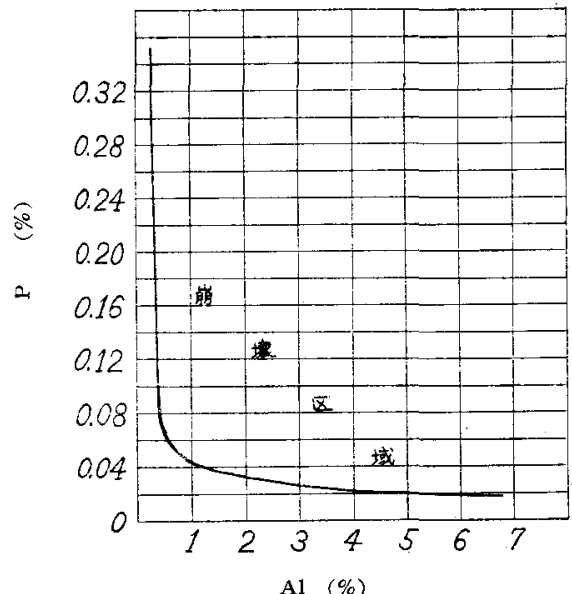

図 28 FSi 崩壊に及ぼす Al, P (\%)の臨界曲線 
い場合，空気中の湿分と不純物が反応し崩壊性をおびる た为注意が必要である。参考まで㙁谷らうらよって示 された崩燷領域を示すと図 28 のようである。

またFSi は水との接触により徐々に反応して $\mathrm{PH}_{3}$ な ぞ有表ガスを含んだ $\mathrm{H}_{2}$ を発生し ${ }^{67}, \mathrm{H}_{2}$ の発生は食塩水 で惊とくに著しい，てのガス発生は FSi 表面を適当な

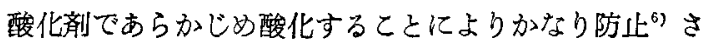
れるが実用化はされていない，このため製品の保管輸送 とくに海上輸送には注意が必要である。

6.1.2 電炉設備 FSi 製造用炣として一般つェ ロアロイ用電気焒と同様ゼーダーベルグ電極を用いた開

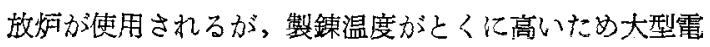
妒が有利であり，一般に 5,000 10,000 kVA 程度の大 型焐か使用され，ノルウエーでは $20,000 \mathrm{kVA}$ 炉床回転 型電炀が操業されている。

ライニングは哣をカーボンとし炉照活シャモット耐火 レンガが使用され，メタルは通常カーボン製鋳床に直接 タップし，タップホール注小型焰では一つの場合が多い

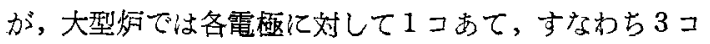
設ける場合が多い。

$Q=t \mid \rho(9,480+72,310 / \sqrt{p)}+(1-t) 1000 \quad$ (32)

$Q:$ 電力原単位 $\mathrm{kWh} / \mathrm{t}$ (ただし Fe 原としては銅 ダライ使用)

$t:$ 製品 $\mathrm{Si}$ 品位 $\%, \rho: \mathrm{Si}$ 収率,

$p:$ 操業時の負荷 $\mathrm{kW}$

炤容量と製品品位わよび電力原単位の関係について

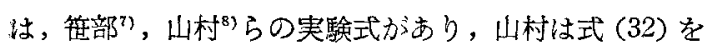
与元品位および炉容量の差による電力原単位の差異はか なり大である。

弱が大型化するときにクラストの生成を排除するた め, 回転炤床型電㚸が有効であり ${ }^{92}$, 最近はポーキング マシンる市販活用される傾向にある.電極面間距離注電 極直径の 1.2 1.4 倍程度とされ, 操業電圧は炣定数お よび使用炭材によって異なるが，表 7 より明らかなよう に FMnH に比べ $\mathrm{PH}$ が比較的大であるため，比較的 高く $2,000 \sim 3,000 \mathrm{~kW}$ 炬で $80 \sim 90 \mathrm{~V}, 7,000 \mathrm{~kW}$ 炻で $110 \sim 130 \mathrm{~V}$ 程度である.

MSi の場合は，電極およびヶースから Fe その他の 不純物が混入することをさけるたもぜーダーベルグ電極

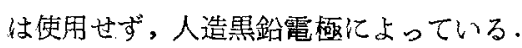

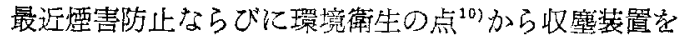
付設する傾向少強い，

\subsection{3 製造および研究 FSi 製造原料としては一}

表 47 ケイ石および白ケイ石組成例 (\%)

\begin{tabular}{l|r|r|r|r|r|r|r}
\hline & $\mathrm{SiO}_{2}$ & $\mathrm{Fe}_{2} \mathrm{O}_{3}$ & $\mathrm{Al}_{2} \mathrm{O}_{3}$ & $\mathrm{CaO}$ & $\mathrm{MgO}$ & $\mathrm{MnO}$ & $\mathrm{P}$ \\
\hline FSi 用ケ石 & 97.56 & 0.42 & 0.95 & 0.19 & 0.45 & 0.10 & 0.011 \\
$\mathrm{MSi}$ 用白と石 & 99.51 & 0.24 & 0.17 & 0.14 & - & - & 0.007 \\
\hline
\end{tabular}

般に $\mathrm{SiO}_{2} 97 \%$ 以上のケイ石が使用され， $\mathrm{Fe}$ 原として 注鎆ダライもしくはラルスケールが使用されるが，鎆名 ライを使用するの方最も一般的で電力原単位の上からも 有利である。

ケ佦は $\mathrm{Al}_{2} \mathrm{O}_{3}$ および $\mathrm{CaO}$ 含有率の低いものが望 ましく，てれら不純物の含有は電力原単位㧍よご難溶性 スラグを生成して炉況を害するため好ましくない．

ケイ石は一般に愛知県三河もしくは福井県今座産のも のが用いられ，㚸容量化より $7.5 \mathrm{~cm}$ 己くは $5 \mathrm{~cm}$ 以 下にサイジングしたものが購入使用され，MSi用ヶイ石 として蛅不純物のとくに低い白ヶイ石が使用される。

ケイ石および白ケイ石の組成列を示すと表 47 のよう である。

FSi の還元用炭材として法一般にコークブリーズが使 用されるが，㚸況改善のため石炭を20 30\% 混合使用す る場合も多く, また固定宸素70 80\%, 揮発分 4 10\%, 灰分 15〜20\% のコーライトもかなり使用されている。

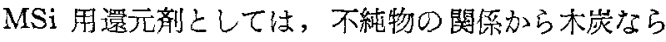
びにピッチコークスおよびオイルコークスが使用され る、炭材の選択は操業電圧わよび炣況にかなりの影響を 与元る。参考までに各種炭材の電気特性を示すと図 29 のようである.

操業はいわ的る抵抗操業によって行なわ的るが，Si 品 位の高いほど㚸況は上显し，電力原単位は大となり $\mathrm{Si}$ 收率は低下する・タップ時間注操業の習慣によって異な

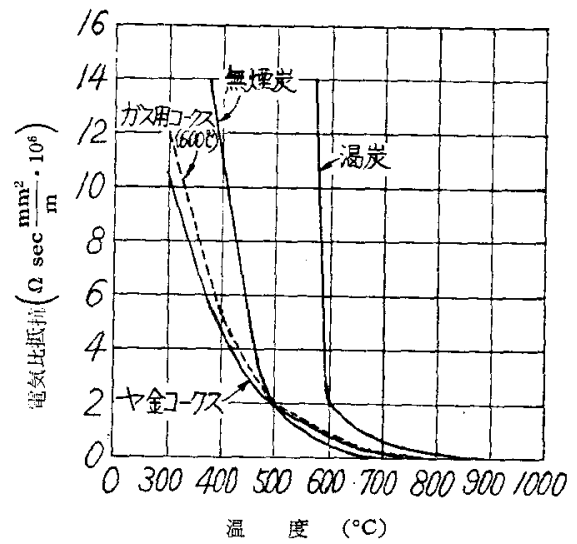

図 29 銑鉄製造時にお子当調合の配合比が鉱石 100 , 焼石扊 25 䄦よび還元材 20 の場合の温度と 雪気此抵抗の関係

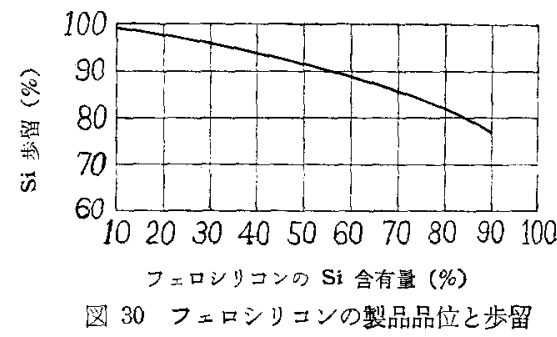


表 48 鉄源を除く FSi 原単位推移

\begin{tabular}{|c|c|c|c|c|c|c|c|c|}
\hline \multirow[b]{2}{*}{ 年 次 } & \multicolumn{4}{|c|}{ FSi 2} & \multicolumn{4}{|c|}{ FSi 3} \\
\hline & $\begin{array}{l}\text { ケイ石 } \\
(\mathrm{kg})\end{array}$ & \begin{tabular}{|l}
$\exists-ク ス$ \\
$(\mathrm{~kg})$
\end{tabular} & $\begin{array}{l}\text { 霓 極 } \\
(\mathrm{kg})\end{array}$ & \begin{tabular}{|l|} 
電 7 \\
(kWh)
\end{tabular} & $\begin{array}{l}51 \text { 石 } \\
(\mathrm{kg})\end{array}$ & 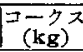 & $\begin{array}{c}(\mathrm{kg}) \\
(\mathrm{k})\end{array}$ & \begin{tabular}{|l|} 
霓 \\
(kWh
\end{tabular} \\
\hline 昭和 30 & 2,157 & 984 & 109 & 11,634 & 1,162 & 680 & 56 & 6,743 \\
\hline 31 & 2,081 & 938 & 99 & 11,050 & 1,123 & 665 & 60 & 6,887 \\
\hline 32 & 2,131 & 903 & 101 & 11,341 & 1,316 & 648 & 59 & 6,668 \\
\hline 33 & 2,071 & 886 & 92 & 10,968 & 1,315 & 655 & 59 & 6,849 \\
\hline 34 & 2,128 & 851 & 84 & 10,982 & 1,123 & 649 & 57 & 6,342 \\
\hline 35 & 2,059 & 806 & 83 & 10,518 & 938 & 578 & 54 & 6,784 \\
\hline 36 & 2,099 & 823 & 77 & 10,424 & 811 & 614 & 41 & 5,485 \\
\hline
\end{tabular}

るが，過度な使用はチップの含有水分および分解熱 のためむしろ成績は低下する．また米国と異なり， わが国ではチップ資源が穵しく割高なととも哭題で あるが，炉洗悪化の際の回復手段としてその利用価 值は十分考慮されてよい。

最近主としてヶイ素鋼板用 FSi として, FSi の 含有Al がケイ素鋼の電気特性を害する ${ }^{14}$ ととから $\mathrm{Al}$ 含有率の低いものがとくに要望される傾向にあ り， $\mathrm{Al}$ 含有率 0.3 および $0.1 \%$ 以下のものも製

表 $49 \mathrm{MSi}$ 製造原単位例

\begin{tabular}{|c|c|c|c|c|}
\hline & 白ケイ石 $(\mathrm{kg})$ & 木 炭 $(\mathrm{kg})$ & 䉓 & 力 $(\mathrm{kWh})$ \\
\hline 例一i & 2,760 & 1,755 & & 16,200 \\
\hline 侧 -2 & 2,680 & 1,814 & & 17,000 \\
\hline
\end{tabular}

るが，3〜6hの範囲で選ばれ，タップ温度は FSi 2 号 品では $1,700 \sim 1,800^{\circ} \mathrm{C}$ である. 製品は泠却時の偏析が 特に大であるため $150 \mathrm{~mm}$ 以下の厚さにタップするとと が望ましい，偏析が大となった場合自然崩壊を助長する 原因となることもある。

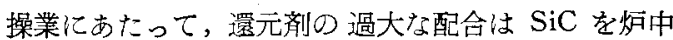
に蓄積して電極および炉底の上昇をきたし，成績低下の 原因となるため注意が必要である，標準的な操業におけ る炉容量と電力原単位は式 (32) によって与えられるが $\mathrm{Si}$ 品位と収率との関係注図 30 のようであり，FSi 2 号ではほぼ 82〜84\% 程度である。

FSi 2 号品扔よび 3 号品の昭和 30 年以降の Fe 源を 除く原単位の概略 ${ }^{11}$ を示すと表 48 のようであり，Si 収 率注漸次向上し電力原単位も低下しているが全国平均值 はいまだ改良の余地のあるととを示している．FSi 2 号 品の電力原単位は，メーカーによっては $9,200 \mathrm{kWh}$ 前 後の成績も得られている。

MSi の原単位例を示せば表 49 のようであり，Si 収 率は 75 80\%，電力原単位は $16,500 \mathrm{kWh}$ 前後である. なお MSi の不純物の主体は Feである。

FSi および MSi の成績向上には，Si の蒸発防止と 熱效率の向上が最も必要であるが，乙の改善手段として 主として通気性と原料面の断熱性改善の見地からウッド チップの有効なことも知られ，米国でかなり一般的に使 朋されている。

ウッドチップの效果 ${ }^{12}$ については表500結果か報告 ${ }^{13}$ され，適当量の配合が效果をあげうるととが示されてい

表 50 FSi 2 製造時のウッドチップ効果 $(3,000 \mathrm{kVA}$ 炉 $)$

\begin{tabular}{|c|c|c|c|c|c|c|}
\hline$=f$ & $\begin{array}{r}\text { プ配合率 } \\
(\%)\end{array}$ & 0 & 19 & 22 & 29 & 37 \\
\hline 電力原单位 & $(\mathrm{kWh} / \mathrm{t})$ & 9,450 & 9,312 & 9,070 & 9,300 & 9,640 \\
\hline 給 颌 量 & $(\mathrm{kg} / \mathrm{Day})$ & 11,600 & 12,700 & 13,000 & 11,700 & 11,700 \\
\hline 生 童 & (kg/Day) & 6,600 & 6,685 & 6,915 & 6,700 & 6,496 \\
\hline
\end{tabular}

注 配合率ニウッドチップ×100/総摆元剂量
造が可能となっている。

これら低 $\mathrm{Al}$ 製品は $\mathrm{Al}_{2} \mathrm{O}_{3}$ 含有量の低いケイ石および 炭材を選ぶだけでは製造困難であるため，いったんFSi を製造してれを酸化鉄わよび石灰などを加光て $\mathrm{Al}$ を優 先酸化する方法 ${ }^{15}$, $\mathrm{FSi}$ 溶湯をアーク炉で $\mathrm{CaO}-\mathrm{SiO}_{2}$ 系 スラグで洗浄する方法 ${ }^{16)}, \mathrm{O}_{2}$ または $\mathrm{Fe}$ 酸化物を $\mathrm{O}_{2}$ と 併用して吹精する方法 ${ }^{17)}$, FSi 溶湯を $\mathrm{Cl}_{2}$ で処理する 方法 ${ }^{18)}$, 溶湯に酸化性フラックスを加方て空気かくはん する方法 ${ }^{199}$ ，使用原料を塩酸もしくは塩化物溶液で処理 して使用する方法 ${ }^{20)} と ゙$ 多くの考案がある。

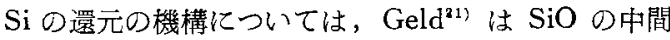
生成と $\mathrm{SiO}$ がCにより還元されて Si が生成されると $し, \operatorname{Remrin}^{22}$ は $\mathrm{SiC}$ が中閻体として生成し, $\mathrm{SiC} か ゙$ 単独もしくはCとともに $\mathrm{SiO}_{2}$ に作用して $\mathrm{Si}$ をるる

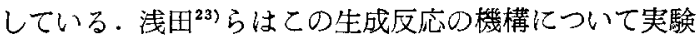

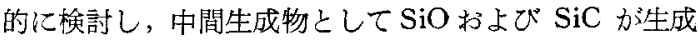
し，乙れらが相互行応して Si を生成するのが主反応 であることを推定するとともに，MgOなどの含有が $\mathrm{Si}$ の還元について触媒的な效果をもつてとを諗めている。

6.2 特殊 Si 系アロイならひに SiAl（シリコンアル ミニウム) およひ SiMg（シリコンマグネシウム）

\subsection{1 特殊 Si 系アロイおよひ $\mathrm{SiAl} \mathrm{Si}$ 系アロイ}

としては, MSi および FSi のほかに米国ではB 0.04 $\sim 0.08 \%$ を含有した B-bearing FSi, Ca 0.5\% 以上 を含有し Al 含有率の低い Ca-bearing low-Al FSi が 製造 ${ }^{24}$ されている．前者は FSI 脱酸もしくは Si 添加 時に微量のBを添加する目的の製品であり，後者は少量 の Ca の含有により Si 添加時の銚中の介在物を特に低 下させる目的で製造されたものであるが，わが国ではい まだ生産されていない，B-bearing FSi の製造は，FSi 㱔造の際少量の $\mathrm{B}_{2} \mathrm{O}_{3}$ もしくはホウ砂 $\mathrm{Na}_{2} \mathrm{~B}_{4} \mathrm{O}_{7}$ を配合 すれば容易に製造され，Ca-bearing FSi は少量の $\mathrm{CaO}$ を配合して容易得られる。

また米国およびわが国际でもフェロシリアルミおよび

表 51 FSiAl および SiMnA] 合金組成例 (\%)

\begin{tabular}{|c|c|c|c|c|c|c|c|}
\hline & $\mathrm{Si}$ & $\mathrm{Al}$ & $\mathbf{M n}$ & $\mathrm{Fe}$ & c & $\mathbf{P}$ & $\mathrm{s}$ \\
\hline FSiAl & 40 & 20 & - & 40 & 0.5 以下 & 0.05 以下 & 0.05 以下 \\
\hline $\operatorname{SiMnAI}$ & 20 & 20 & 20 & Rest & 0.5 以下 & 0.05 以下 & 0.05 以下 \\
\hline
\end{tabular}


表 $52 \mathrm{Mg}$ 系アロイ組成例 $(\%)$

\begin{tabular}{|c|c|c|c|c|c|c|c|}
\hline 別 & $\mathbf{M g}$ & $\mathrm{Si}$ & $\mathrm{Ca}$ & $\mathbf{R}$ & $\mathrm{c}$ & $\mathbf{P}$ & $\mathrm{s}$ \\
\hline & 7 & & - & - & T & 以下 & dF \\
\hline $\mathrm{s}$ & & & - & - & 0 以下 & 5以下 & 0.05 以下 \\
\hline & 13 & & - & - & 0 以下 & 5以下 & 0.05 以下 \\
\hline CaSiMg & $\sim 20 \sim$ & $\sim 50 \sim$ & $\sim 5 \sim$ & - & 1.0 以下 & 0.05 以下 & 10.05以下 \\
\hline Ca䄧よびR含有 $\mathrm{SiMg}$ & $\sim 31 \sim$ & $\sim 60 \sim$ & $\sim 4 \sim$ & $\sim 2 \sim$ & 1.0 以下 & 0.05 以下 & 0.05以下 \\
\hline
\end{tabular}

鋼におけるNの效果に関する研究は，1923 年 Fry $^{32)}$ 亿よる表面処理效果の研究以後 るわて活発となり，1935 年高 $\mathrm{Cr}$ 銅に 対しNが絬晶粒を微細化し耐食狌を害する ことなく機械的性質の改善に有効 $\left.{ }^{33)} 35\right)$ で あること，ならびにオーステナイトの生成 と安定化に有効であり，乙のため Cr-Mn-

シマナールなどの名称で，表 51 の組成の複合脱酸合金 が市販されている，製造は目標成分が得られるように各 成分を有する母合金を配合，合金化する方法によって行 なわれるが，その効果については不明な点が多く，生産 量も少量である。

低品位ボーキサイト，カ才リンおよび粘土などの還元 炕より SiAl 合金学得ようとする試みは比較的古くから 検討 ${ }^{26), 27}$ され, さらにSiAlよりモノクロライド法によ り金属 $\mathrm{Al}$ を製造しようとする試みもなされているが， SiAl の製造预よび精整工程ともに問題 ${ }^{28)}$ があり，新製 錬方法としてとくに有利であるとの見通しはいまだ得ら れていない29.

6.2.2 SiMg 近年ノジェラ一錆鉄の発達により， その製造方法および添加剂についてす多くの提案かなさ 机ているが，最も一般的な方法は $\mathrm{SiMg}$ 使用する方法 である。

現在市販されているSiMg 台金の代表的な組成を示す そ表 52 のうである。

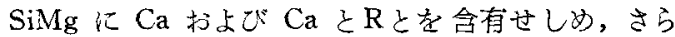
にその効果を助長しようとするタイプの合金も表 52 に

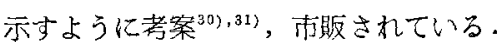

艁造方法としては，一般に $\mathrm{AZ}$ 合金などの比較的 $\mathrm{Mg}$ 以外门合金成分の少ない $\mathrm{Mg}$ 合金スクラップ，また㳊金 属 $\mathrm{Mg}$ 乙 FSi を $\mathrm{Mg}$ 溶解用フラックスを使用して黒 鉛ルツボを朋い，保謢溶解する方法がとられている。 CaSiMg 台金および Ca とRを含有する SiMg 亿つい ては，溶解の際必要量の CaSi 抢よび金属Rを配合して 製造される。もちろん R の添加は RCaSi と同様 $\mathrm{RCl}_{3}$ と $\mathrm{CaSi}$ にょても行なうこ とができるいずれの合金も溶解操作にあ たり $\mathrm{Mg} の$ 揮発損失の䟙止には特に注意が 必要である。

乙れらの合金の性状仕，CaSi 亿比較的 近似している。生産量は明確で泳ないが， ノジュラー鎍鉄の生産の伸びにそってかな りの量になっていると考えられる。

$7 \mathbf{N}$ 化アロ1，熱性アロ1 およびブリケットアロイ

\subsection{FCrN および NMn}

\section{1 .1 沿革亡規格,用途およひ性横 鉄}

$\mathrm{Ni}$ 鈵中の $\mathrm{Ni}$ のかなりな量をNによっておきかえるこ

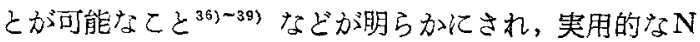
化鋼の製造がにし多られるようになって，N母合金の製 造も検討されてきた。

N母合金としては，その使用目的が含Nオーステナイ

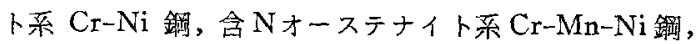
$\mathrm{Cr}-\mathrm{Mn}$ 鋼，含 $\mathrm{N}$ フェライト系扔よびマルテンサイト系 高 $\mathrm{Cr}$ 鋼が主体であるととから，Cr 叔よび $\mathrm{Mn}$ と $\mathrm{N}$ とを同時添加する目的から $\mathrm{FCr}$ ならびに金属 $\mathrm{Mn} の$ N化物方検討され奏用化された。

高張力用りムド鋼にもN沬きわめて有效であるが，と の目的には FMnM のN化物方検棓夷用化された。

N含有率 $1 \%$ 前後の JIS 規格 FCrN, およびN含有 率 5 6\%00市販 FCrN，抢上び市販 NMn合金の組成 を示すと表 53〜54 Dようである。

N化アロイ添加時のN收率は刘象銅種および目標N 96 で異なるが，N含有率 $1 \%$ 前後の FCrN の場合は $90 \%$ 以上の高収率を示すが，N含有率 5〜69 FCrN O場合 は添加時に熱分解によるNの放出が多いため收率は70 $\%$ 前後に低下し，N化電解 $\mathrm{Mn}$ も活活同程度の収率を 示す.

しかしながら一般的に有效N当たりのコストは，N含 有率の高いるのの方が格安とされている。

参考までに化アロイの使用刘象鋼䅜を一括して示せ ば表 55 のようである。

JIS 規格 FCrN の性状は，続䇉に述べる FCrLに近 似した性状を示し，銀塊の破砕物として市販されるが， 表 53 FCrN の JIS 規格

\begin{tabular}{|c|c|c|c|c|c|c|c|c|}
\hline \multirow{2}{*}{ 種 } & \multirow{2}{*}{ 别 } & \multirow{2}{*}{ 記 号 } & \multicolumn{2}{|r|}{ 化 } & 学 & 戎 & \multicolumn{2}{|l|}{ (\%) } \\
\hline & & & $\mathrm{Cr}$ & $\mathrm{N}$ & $\mathrm{Si}$ & c & $\mathbf{P}$ & S \\
\hline 高 窒 素 & 1 号 & $\mathrm{FC}_{\mathrm{N}} \mathrm{N} 1$ & $60 \sim 65$ & 1.25 以上 & $1.0 \mathrm{WF}$ & 0.1 以下 & $0.04 \mathrm{WT}$ & 0.03 以下 \\
\hline ᄀ.. & 2 묵 & FCrN 2 & $60 \sim 65$ & 1.0022 & 1.0 以下 & 0.1 以下 & 0.04以下 & 0.03 以下 \\
\hline 8 & 3 号 & FCrN 3 & $60 \sim 65$ & 0.75 以上 & 1.0 以下 & 0.1 D下 & 0.04 以下 & $0.03 \mathrm{WF}$ \\
\hline
\end{tabular}

表 54 市販 FeCrN むよび NMn の組成例

\begin{tabular}{|c|c|c|c|c|c|c|c|c|}
\hline \multirow{2}{*}{ 種 別 } & \multirow{2}{*}{$\$ 17^{\circ}$} & \multicolumn{3}{|c|}{ 化 } & 組 & \multicolumn{3}{|c|}{ (\%) } \\
\hline & & $\mathrm{Cr}$ & $\mathrm{Mn}$ & $\mathrm{N}$ & $\mathrm{Si}$ & c & $P$ & $\mathrm{~s}$ \\
\hline \multirow{3}{*}{$\mathrm{FCrN}$} & A & $56 \sim 62$ & - & $5.0 \mathrm{DL}$ & 1.0 D下 & 0.1 D下 & 0.04 以下 & 0.03 选下 \\
\hline & B & $\sim 55 \sim$ & - & $\sim 5.8 \sim$ & $\sim 7 \sim$ & 0.1 以下 & $0.04 \mathrm{WF}$ & 0.03 以下 \\
\hline & c & $\sim 41 \sim$ & - & $\sim 5.8 \sim$ & $1.0 \mathrm{DT}$ & 0.1 以下 & 0.04 以下 & $0.03 \mathrm{DT}$ \\
\hline \multirow[t]{2}{*}{$\mathrm{MnN}$} & Met. $\mathrm{MnN}$ & - & $\sim 92 \sim$ & $\sim 6.5 \sim$ & $0.01 \mathrm{NT}$ & 0.01 以下 & 0.01 以下 & 0.04 以下 \\
\hline & $F M n N$ & - & $\sim 70 \sim$ & $\sim 5.0 \sim$ & $\sim 1.5 \sim$ & $\sim 1.5 \sim$ & $\sim 0.2 \sim$ & $\sim 0.01 \sim$ \\
\hline
\end{tabular}


表 $55 \mathrm{~N}$ 化厂ロイの使用対象鋼種

\begin{tabular}{|c|c|c|c|c|c|c|c|c|c|c|c|c|c|}
\hline 別 & 称 & $(\%)$ & $\begin{array}{l}\mathrm{Si} \\
(\%)\end{array}$ & $\begin{array}{l}\mathrm{Mn} \\
(\%)\end{array}$ & $\begin{array}{l}\mathrm{Cr} \\
(\%)\end{array}$ & $\begin{array}{l}\mathbf{N i} \\
(\%)\end{array}$ & $\begin{array}{l}W \\
(\%)\end{array}$ & Mo & (\%) & $(\%)$ & $\begin{array}{l}\text { Nb } \\
(\%)\end{array}$ & $\begin{array}{c}\mathbf{N} \\
(\%)\end{array}$ & $\begin{array}{l}\text { そo他 } \\
(\%)\end{array}$ \\
\hline \multirow{2}{*}{ 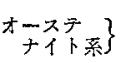 } & Als1 201 & 0.15 以下 & 1.00以下 & $5.50 \sim 7.50$ & $|16.00 \sim 18.00|$ & $|3.50 \sim 5.50|$ & - & - & - & - & - & 0.25 以下 & \\
\hline & Al\$1 202 & 0.15 以下 & 1.00D下 & $7.50 \sim 10.00$ & $17.00 \sim 19.00$ & $4.00 \sim 6.00$ & - & - & - & - & - & 0.25 以下 & \\
\hline フ:ライト系 & AlSl 446 & $0.20 \mathrm{WT}$ & 1.00D下 & 1.50 以下 & $23.00 \sim 27.00$ & - & - & $(0.40)$ & - & - & - & 0.25 以下 & \\
\hline $\mathrm{Mn}-\mathrm{Cr}-\mathrm{V}$ 系 & Cromadure & $0.10 \sim 0.20$ & $|0.80 \sim 1.20|$ & $13.0 \sim 15.0$ & $10.0 \sim 12.0$ & - & - & - & - & $0.6 \sim 0.8$ & - & $0.10 \sim 0.20$ & \\
\hline 15-4 PH & AM-355 & 0.13 & 0.50 & 0.95 & 15 & 4 & - & 2.75 & - & - & - & 0.10 & \\
\hline 16-25 䒺 & Timken & 0.1 & 0.9 & 1.5 & 16 & 25 & - & 6 & - & - & - & 0.15 & \\
\hline 20-30 系 & TE & 0.1 & 0.5 & 0.7 & 20 & 30 & 4 & 4 & - & - & - & 0.15 & $\begin{array}{ll}\text { Ta } & 1.9\end{array}$ \\
\hline \multirow{2}{*}{$\left.{ }_{\text {委 }}^{15-14-\mathrm{Co}}\right\}$} & HCN -153 & 0.4 & 0.5 & 1.8 & 16 & 15 & 2 & 3 & 13 & - & 1 & 0.1 & \\
\hline & LCN-153 & 0.1 & 0.5 & 1.8 & 15 & 15 & 2 & 3 & 13 & - & 1 & 0.1 & \\
\hline \multirow{3}{*}{$\left.\begin{array}{l}16-25-C o \text { 系 } \\
\text { 低炭素鋼 } \\
\text { " }\end{array}\right\}$} & N- 154 & 0.3 & 0.7 & 1.6 & 16 & 24 & 2 & 3 & 21 & - & 1 & 0.1 & \\
\hline & $1 \mathrm{~N}$ 屚 & 0.17 & 0.33 & 0.87 & 0.04 & 0.08 & - & - & - & - & - & 0.020 & $\mathrm{Cu} 0.13$ \\
\hline & $1 \mathrm{~N}$ 銅 & 0.09 & 0.26 & 0.85 & 0.51 & 0.83 & - & 0.44 & - & 0.055 & - & 0.025 & $\mathrm{Cu} \quad 0.33$ \\
\hline
\end{tabular}

N含有率 $5 \sim 6 \%$ 6のは後述する製造方法から，ブリ ケットもしくは焼結物の破硭品として市販される。

またN化金属 Mn はフレータ状，N化 FMnM はブ リケット状のものか通例である，FCrNは此較的水分お よび湿分に安定であるが，MnのN化物は水との接触 により分解して徐々に $\mathrm{NH}_{3}$ を発生するため, 水との接 触には注意する必要がある。

7.1 .2 製造ならひに研究 FCrN および NMnの 製造方法は，溶融メタルに $\mathrm{N}_{2}$ を作用させてる方法と比 較的低温において固体状で反态させる方法の 2 種類が考 光ら机る。

$\mathrm{FCr}, \mathrm{FMn} の \mathrm{Cr}$ および $\mathrm{Mn}$ 含有率，ならびに温度 とNの飽和吸收量の関係については，岩瀨 ${ }^{40)}$ ，斎藤 ${ }^{41)}$ 研究により図 31,32 方沶されており，FCr,FMn と多に かなりのNを吸収するが，その败收量は低温度の方が大

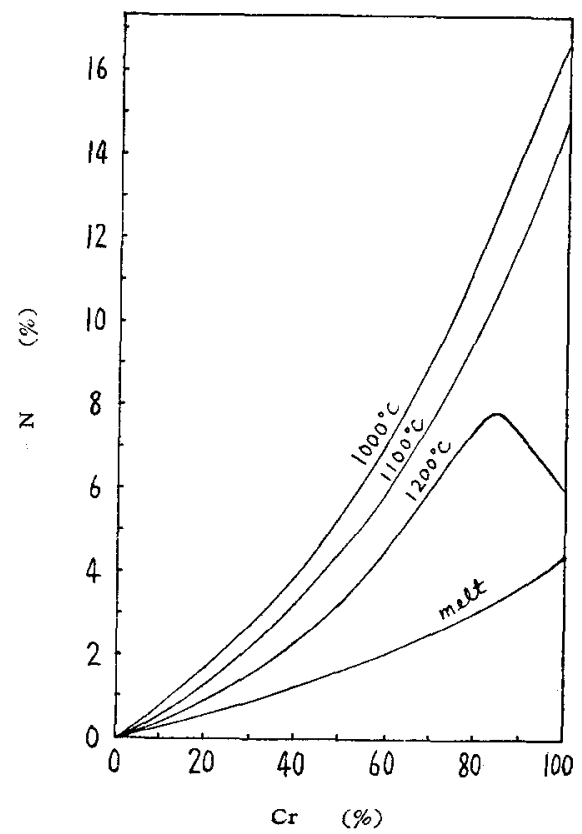

图 $31 \mathrm{FCr}$ 合金に打ける温度抒よび $\mathrm{Cr}$ 品位と $\mathrm{N}$ 平衡含有率との関係
であることから，製品の $\mathrm{N}$ 含有率から考虑した場合，当 然固体N化の方が望ましい。

しかしながら固体N化の場合拡散速度が小であるた め，当然粉未もしくは薄片とすることが必要であり，比 較的粉砕性のよい FMnM および原料自体がフレーろ状 で生産される電解 $\mathrm{Mn}$ では当然この方法が採用され， Mn の蒸気圧の高いてとからも固体N化が望ましく，溶 融メタルに $\mathrm{N}_{2}$ を吹き込む方法は全く行なわ机ていな w.

しかしながら比較的粉砕の 困難な FCrL の場合は， FCrL の最終工程にむいて炉中生成した溶融 FCr に 適当な方法により， $\mathrm{N}_{2}$ もしくは $\mathrm{N}_{2}$ と $\mathrm{NH}_{3}$ を吹き込 みN化を行なう方法も採用され，JIS 規格品はもっぱら この製造方法によっている。

図 31 から明らかなように，Cr 60\%の溶融 FCrの N飽和吸收量はほぼ1.5\%で比較的低いため，Nの収率 は比較的低い。このためガス吹き込み方法についても考

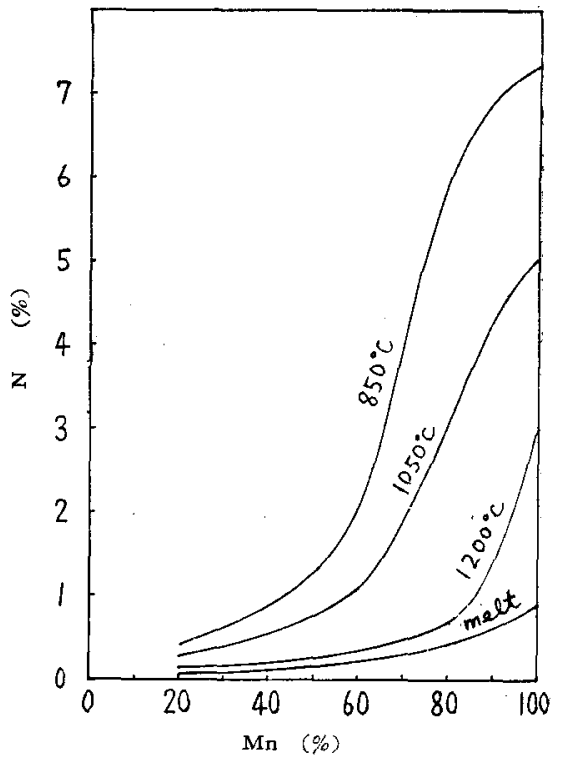

四 $32 \mathrm{FMn}$ 合金における温度および $\mathrm{Mn}$ 品位と $\mathrm{N}$ 平衡含有率との関係 
案“2゙があり，またガス吹き込みを行なうかわりに Si $5 \%$

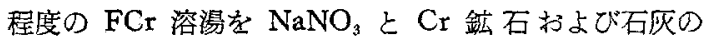
混合物之混合し，N化反応を行なうと同時使留 Si 除去を行なう方法“31，および FCrL 製造侮して SiCr に AlN p $\mathrm{CrSiN}$ 系合金などを併用して FCrNをうる 方法などの考案 ${ }^{45}$ がある。ま゙ FCr 粉末に硝酸塩と硝 酸塩に反応する強辠元粉末を混合反応させ，発生 $\mathrm{N}_{2}$ を $\mathrm{FCr}$ に吸收させて FCrN をうる方法などの提案 ${ }^{45}$ る なされている。

一方 FCr の固相 N化によるN含有率の高い FCrN の 製造も行なわれているが，ての場合 FCrL 加粉砕困難 なため粉碎方法についてはとくに考察がはらわれる。

FCrL の Si 含有率を 5 7\% 程度として粉碎を容易 とし, -60 mesh の粉末として適当な反応容器内で 1000 $\sim 1100^{\circ} \mathrm{C}$ 亿加熱 $\mathrm{N}$ 化する方法 ${ }^{46}$ による場合，表 54 タイ プ $\mathrm{B}$ が得られ，Cr $45 \%$ ○ $\mathrm{FCrL}$ を $750^{\circ} \mathrm{C}$ 程度に加熱。 ぜい性を与光粉挽後N化した場合タイプCが得られる。

タイプA J IS 規格品位の FCrLを水碎ショットと して後粉砕して粉末とするか，または切削して薄片状と 乙同様化N化を行なって製造される。

ての上うにして得られたN含有率 5.5 6.5\% の反広 物は，粉辞後遥当なバインダーを混台してブリヶットと するか，もしくはN化反応終了物は比較的強く烧続して いるため，焼結塊を適当るサイズに粉砕して製品化され る。

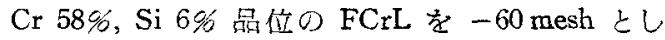
て, N平衡含有率と温度の関係を求めた結果は図 33 の ようであり，1,150 1,100 $\mathrm{C}$ で $\mathrm{N}$ 含有率は最高值の6.3 \%江達古る。

粒度は一 60 mesh 以下であれば影響はない。

$\mathrm{N}$ 化電解 $\mathrm{Mn}$ 泣電解 $\mathrm{Mn}$ を特に粉秓せず $850^{\circ} \mathrm{C}$ 付 近で $\mathrm{N}_{2}$ ふんい気で反応せしめて得られるが，反応が内 部まで十分に到達しないため $\mathrm{N}$ 含有率は一般に $6.5 \%$ 程 度である。

$\mathrm{Mn} 76 \%, \mathrm{Si}$ 抢よびC含有率 $1.5 \%$ ○MnM -60

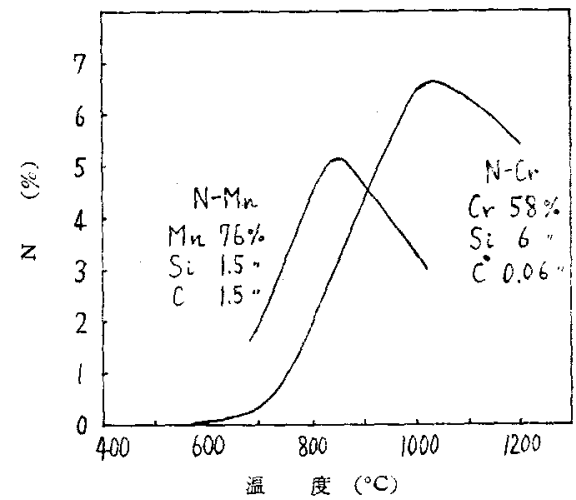

因 33 FMn拉よび FCrL の反温度と $\mathrm{N}$ 乎衛含有率 mesh 粉末の反応温度と $\mathrm{N}$ 平衡含有率を検討した結果は 図33 亿併記したとおりであり，N合有率は $850^{\circ} \mathrm{C}$ で最 高值 $5.2 \%$ を示している。

$\mathrm{N}$ 化反応に要する時間は反応規模でも異なるが $\mathrm{FCrL}$ および FMnM の場合，常圧下最適温度で 40 60h 程 度である. $\mathrm{NH}_{3}$ を $\mathrm{N}$ 源として使用すればさらに高品位 のものが得られる可能性も考慮されるが， $\mathrm{NH}_{3}$ は合金 粉末との接触により迅速份分解するため, $\mathrm{NH}_{3}$ が值接 接触する部分だけがN合有率は高くなり，合金粉末充て ん層の内部に対しては単に $\mathrm{N}_{2}$ \& $\mathrm{H}_{2}$ の混合気体とし て作用するため望ましくない。

また FCrIにについて，次回に述べる Simplex タイ プのものは多孔性であるため比較的N化も容易であり， 米国ではかなり製造されている。

\section{2 発熱性フェロアロイ}

7.2 .1 治革之規格，用途および性質 製鋼時の合金 元秦の添加は，電気焗においてはふんい気，スラグの性 筫，浴温の調節が比較的容易であるため收率も高いが，

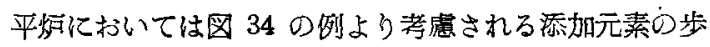
留，ならびに製鋼能率の点からも可及的にレードル添加 するととが望ましい。またキユポラにおける特殊元素の 添加についても, 成分のばらつき防止, 前後の溶湯污染 防止などの見地から考慮した場合，任意の元素が適時レ ードル添加されるととが望ましい。

しかしながら，レードルでの添加合金量が大をなった 場合は溶湯の過令，成分元菜の㻞析などの障害が当然考 慮される。このため低合金鋼，特殊鋳鉄などのような添 加元素の比較的大量なものについて，合金のレードル添 加が円滑に行なわれることを目的として，合金に発熱性 を与立合金添加による温度低下を防止し，迅速な溶解分 散が行なわれるよう考虑されたのが発熱性フェロアロイ である、この考案は $\mathrm{Udy}^{47}$ 亿よってなされ，1939 年 Chromium Mining and Smelting Corp.によって生産

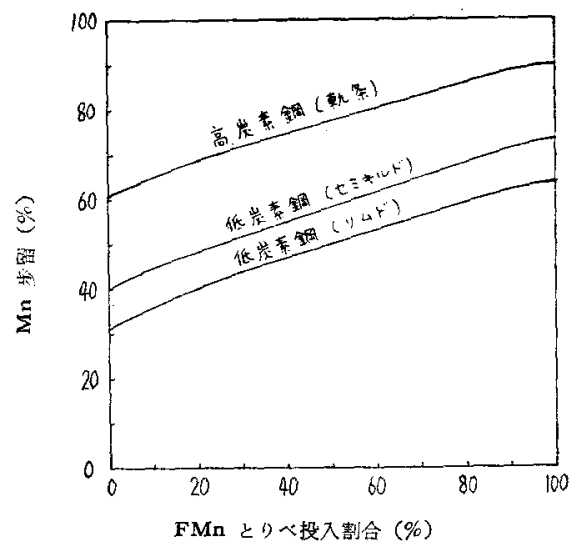

図 34 塩基性平灯にお抄る FMn とりべ使用 割合と $\mathrm{Mn}$ 步留の関保 
表 56 国産 EXO-Alloys 組成例

\begin{tabular}{|c|c|c|c|c|c|c|c|c|}
\hline \multirow{2}{*}{ 種 } & \multicolumn{3}{|c|}{ 化 } & \multicolumn{4}{|c|}{$(\%)$} & \multirow{2}{*}{$\begin{array}{l}\text { 発熱 量*** } \\
(\mathrm{kcal} / \mathbf{k g})\end{array}$} \\
\hline & Mn & $\mathrm{Cr}$ & $\mathbf{T}-\mathbf{S i}$ & 有効 $\mathrm{Si}^{*}$ & $\mathrm{C}$ & $\mathbf{P}$ & $\mathbf{s}$ & \\
\hline EXO-FMnH & $65 \sim 70$ & - & 4 以下 & 2.0 以下 & 7.0 以下 & 0.35 以下 & 0.05 以下 & $180 \sim 220$ \\
\hline EXO-FMnM & $70 \sim 75$ & - & 4 以下 & 2.0 以下 & 2.0 以下 & 0.35 L下 & 0.05 以下 & $180 \sim 220$ \\
\hline EXO-FMnL 1 & $70 \sim 75$ & - & 4 以下 & 2.0 以下 & 1.0 以下 & $0.35 \mathrm{~W}$ & $0.05 \mathrm{W下}$ & $180 \sim 220$ \\
\hline EXO-FMnL 2 & $70 \sim 75$ & - & 4 以下 & 2.0 以下 & 0.10 以下 & 0.10以下 & 0.05以下 & $180 \sim 220$ \\
\hline EXO-SiMn 1 & $55 \sim 60$ & - & $15 \sim 20$ & $14-$ & 2.0 以下 & 0.30 以下 & 0.05 以下 & $180 \sim 220$ \\
\hline EXO-SiMn 2 & $55 \sim 60$ & - & $30 \sim 35$ & $28 \sim 32$ & 0.10 以下 & $0.10 \mathrm{X下}$ & 0.05 以下 & $180 \sim 220$ \\
\hline EXO-FCrH & - & $50 \sim 55$ & 8.0 D下 & 6.0 D下 & 7.0 以下 & 0.04 DF & 0.05 以下 & $180 \sim 220$ \\
\hline EXO-FCrL & - & $50 \sim 55$ & 8.0 以下 & 7.0 以下 & 0.10 以下 & 0.04 以下 & 0.05 以下 & $180 \sim 220$ \\
\hline EXO-SiCr & - & $30 \sim 35$ & 35.0 以上 & 35.0 以上 & $0.10 \mathrm{~L} 下$ & 0.04 以下 & 0.05 以下 & $180 \sim 220$ \\
\hline EXO-FSi & - & - & 70.0以上 & 70.0 贝上 & 0.2 以下 & 0.05 以下 & 0.05以下 & $180 \sim 220$ \\
\hline
\end{tabular}

*発熱刘として反底スラグ化する Si の補正後の值

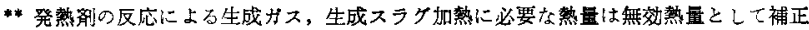

が始められ，ついでU.C.C.によって工業化された。

わが国でも昭和 33 年より生産が始められ，発熱性 FCr，FMn，FSi などの生産利用が行なわれている。乙 れらの代表的組成を示すと表 56 のようである。

このはか FNb，FVなど必要に応して製造されてい る。 EXO-FCr 使用時の $\mathrm{Cr}$ 収率は一般に $95 \%$ 前後とさ れ，EXO-FMn 使用時の Mn 収率は $85 \%$ 前後であり， $\mathrm{Cr}$ 抢よび $\mathrm{Mn} の 2 \%$ 程度までの添加は鋼ならびに鋳 鉄ともに可能である.発熱アロイは発熱剤として $\mathrm{NaNO}_{3}$ なよ゙の酸化剮を含有しているため，かん入として保存市 販されるのが通例で，水分および熱との接触をさけるこ とが必要である。

現在発熱性アロイは，低合金鋼抢よび特殊䤻鉄用とし て，EXO-FCr，EXO-FMn を主体としてかなりの量が 生産利用されていると考えられるが，生産量は明らかで 妃。

7.2 .2 製造およひ研究 発熱性アロイはいずれの品 種についても，図 35 に示すフローシートによって製造 される・すならと対象となるフェロアロイを -10 mesh

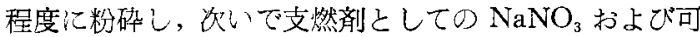
熱物として FSi，CaSi，FSiAl，Al などの粉末または口 シンなどの有機物の計算量を少量の水ガラスなどのバィ ンダー，および少量の $\mathrm{CaF}_{2}$ など反応促進剤とともに添 加混練し，製団後乾燥して製造される。

乾燥の祭発熱剤沙写真 1 のうに合金表面に融着状と なり，合金粉宋之発熱剂の分離が防此される。ブリケッ 卜状とせず粉末のまま乾燥してかん詰とし，かん入りの まま使用されることもある. $\mathrm{NaNO}_{3}$ の使用量は $8 \%$ 前

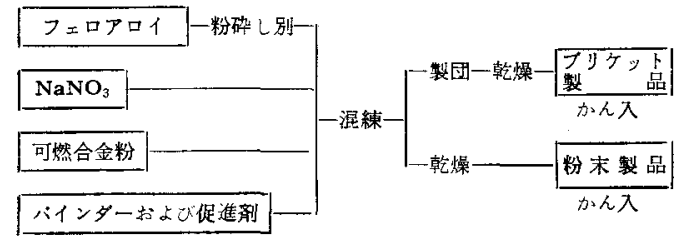

図 35 発熱性フェロフロイ製造フローシート

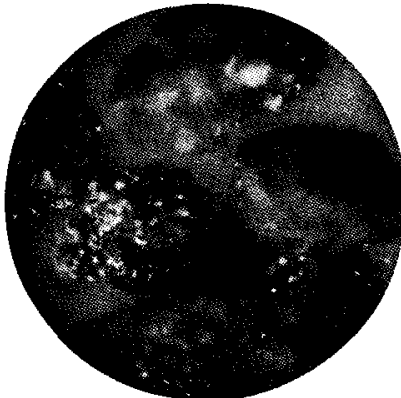

写真 1 発熱剂のアロイヘへの融 着状況 $(\times 50)$

後であり，目的々する発熱量により 増減される。

可然物としては，CaSi しくは CaSi と FSi の混 合物が適当と考えられ，有効発熱量は一般に 180 220 $\mathrm{kcal} / \mathrm{kg}$ 程度で生産されている。

発熱アロイは溶鋼または溶銑に添加されると，ただち に発熱剤の然焼により発熱し，一般に 15 25 sec 程度 で溶解は完了する．発熱褾し， $\mathrm{NaNO}_{3}$ は分解してか なりの $\mathrm{N}_{2}$ を発生して合金粉末の分散を助け，また同時 に分解生成する $\mathrm{Na}_{2} \mathrm{O}$ は粘性の低いララックスを生成し て合金粉末をカバーし，合金の溶湯への親和性を増大し て溶解を助けるものと考光られる. $\mathrm{EXO}-\mathrm{FCr}$ を $900^{\circ} \mathrm{C}$ のふんい気にそう入して $45 \mathrm{sec} の$ 経過を観察した結果

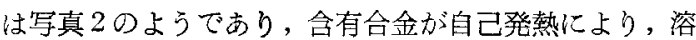
融点近くまで昇温することが示されている。

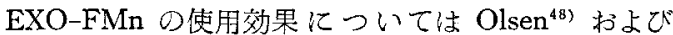
Kimberly $^{49}$ らの報告功あり，図 36 亿示すように Mn

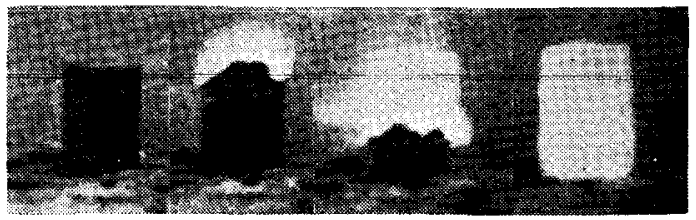

写真 2 発熱状況 (EXO-FCrH)

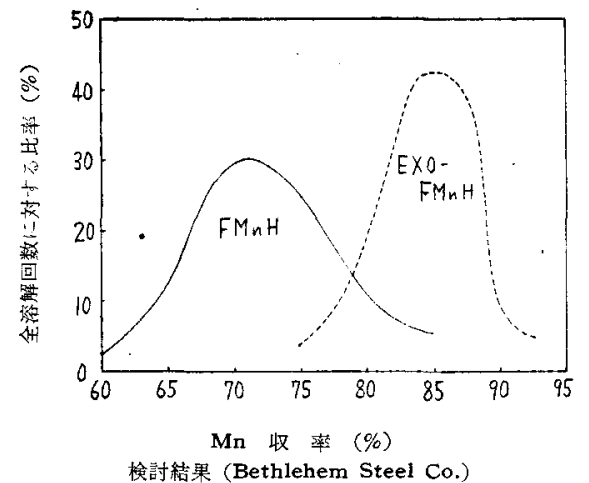

図 $36 \quad \mathrm{FMnH}$ と $\mathrm{EXO}-\mathrm{FMnH}$ の $\mathrm{Mn}$ 收率比較 
表 57 市貶ブリタットアロイ例

\begin{tabular}{|c|c|c|c|c|c|}
\hline 種 & 別 & 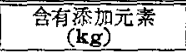 & 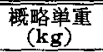 & 形 & 告 \\
\hline FMn & プリケット & Mn 1.0, 0.5 & 2,1 & 長方形 & 触急要 \\
\hline FSi & ブソとット & $S i 1.0,0.5$ & 2,1 & 乃柱状 & 戻色 \\
\hline SiMn & ロプリケット & Mn 0.5 , Si 0.25 & 1.2 & 立方体 & 灰色 \\
\hline FCr & ブリタット & Cr $1.0,0.5$ & 2,1 & 六角柱状 & 黄色 \\
\hline
\end{tabular}

双率の向上とばらつきの減少が明確に示されたと報告 ${ }^{49}$ され，また通常 FMn とEXO-FMnの $1: 1$ の併用の 有効 ${ }^{48)}$ なとる報告されている。

\section{3 ブリケットアロイ}

鋳鉄のキユポラ溶解時の合金元素添加は炣頂ならびに 炉前で行なわ和るが，烦頂添加の場合，通常フェロアロ イを使用したときにはつェロアロイが溶解带に達するま でに酸化消耗を受けやすく，サイズす不均一であるため 均一な溶解が望めず，とのため溶湯成分がばらつきやす い欠点方考慮される。

ブリケットアロイはこれらの久点を改善する目的で， 対象フェロアロイを $-15 \mathrm{~mm}$ 程度に粉碎し，てれにポ ルトランドセメントその他の適当な結合剤を配合成形し て，一定形状のブリケットとしたものである.

1 コ中に一定量の添加元萦を含有し，使用にあたって は計量の手数を省くことができ，また形状および着色に よって品種を区別し，管理を容易にすることができるな どの利点がある。

使用にあたっては，結合剤により溶解体㑢するまで の酸化消耗がある程度防止され，形状も一定しているた 邓溶解速度も注ぼ一定化するふどの利点が期待される。

欧米で注办子り古くから活用され，その普及率もかな

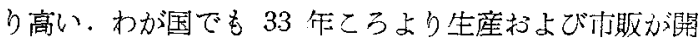
始され，FSi ブリケット，FMn ブリケットが申心をし て使用されているが，その普及率はいまだ比較的低く， 生産量なども明らかでない。

わが国の市販ブリケットアロイの例存示せば表 57 の ようであり，通常アロイに比べ収率は 5 10\% 程度高く 添加元素の步留は $\mathrm{Mn}$ で 85\%, Si で 90\%, Cr で 95 \%程度の収率が得られるとされている。

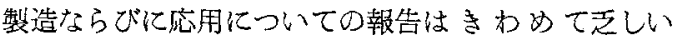
が，収率の向上ならびに添加元素成分のばらつき低下は 比較的明瞭汇認められる。

酸性キユポラで泳焒の中心部にそう入することが望ま しく、ブリケットは運般中に破損することははとんどな 小。

場合によっては，ブリケットの中央部に切目を付し
1/2 として使用ふ河能なように考慮される場合もある。 (昭 38-5-18 受理)

\section{文献}

1) E.S. Greiner, J.S. Marsh, "The Alloys of Iron and Sillicon" 5 (1933). McGraw-Hill Book Comp New York.

2）笹部誠,フェロアロ1 No. 61 (1957).

3) Chalmat, U.S. Pat. 602,975, 602,176 (1895).

4) 岩頼磨三，岡本正三，二元合金つ標染状態図，287. (1953)，日刊工 業新聞社

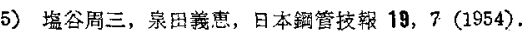

6) 嶺村雄二フコロロアロ1 No. 777 (1957).

7) 笹部誠, フェロアロイ No. 312 (1953).

8) 山村昭, フェロアロイ No. 17356 (1962)

9）塩谷周三，鉄飞鍓 48，1076 (1962).

10）伊繁治フコロアロ1 No. 14126 (1962).

11）フェロアロ势会統計瓷料

12）三須昭，コェロアロイ No. 672 (1957)

13）㙁谷周三，鉄と銅 48，1081 (1962).

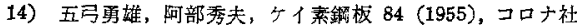

15) 鉄舆社, 特許公 昭 29-8402.

16) ピッペーグメタラシカルカンパニー, 特許公 昭 33-7604.

17) 日本銅管, 特許公 昭 36-14109.

18) Ger $1039752(1960)$

19) USSR 136402 (1961).

20) 鉄興社, 特許公 昭 35-18259.

21) P.V. Geld et al. Stal 7, 706 (1947)

22) V.P. Remrin, Stal 7, 702 (1947).

23）浅田一雄，泳，本誌 31，255（1963）。

24）米国ユニオンカーパイト往製品力夕ロク

25）東化工製品为名年

26) W.P. Eljutin, J.A. Pawlow, B.E. Lewix, Ferrolegierungen 103 (1953).

27) O.C. Fursman, L.H. Banning, U.S. Bur. Mines Rept. Invest. No. 5575 (1960).

28）田辺伊佐雄，昭和 38 年 6 月高純度金属委員会，報告资料

29) J. Glasser, W.E. Few, J. Metals 14, 126 (1962).

30) 信越化学, 特許公昭 28-2207.

31) スタルダゼルシャフトアタチエンゲャルシャフト特新公 昭 33 2110.

32) A. Fry, Stahlu. Eisen 43, 1271 (1963)

33) R. Franks, Trans. Amer. Soc. Metals 23, 968 (1939).

34) W. Colhecch, R.P. Garnea, J. Iron Steel Inst 139, 99 (1939).

35) V.N. Krinohok, Metal Progress, 26, 21 (1934).

36) C.B. Post, E.S. Ehenly, Trans. Amer. Soc. Metals 43, 243, 759 (1950).

37) R. Scherer, Iron Age. 2, 35 (1941).

38) R. Scherer, G. Riedrich, Stahlu Eisen 62, 347 (1942).

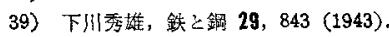

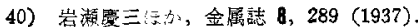

41) 窗藤恒三, 金属䞏 21,1 (1950).

42）日本鋼管 $\mathrm{K} \mathrm{K}$ ，日本特許 221640 .

43) 塩谷周三ほ办，特許公 昭 34-10421

44）加藤絊一，田辺伊佐雄，特部公 昭 35-13806.

45）藤思輝夫，菁示正次，特許公昭 30-6254.

46) 加藤絃一, 田辺伊佐雄, 特部公 昭 33-36756.

47) M.J. Udy, U.S. Pat. 2243786 (1941), B. Pat 520331 (1940), ibid 554330 (1942).

48) W.A. Olsen, J. Metals 10, 614 (1958)

49) P.L. Kimberly, T.V. Wainwright, J. Metals 10, 612 (1958). 